\title{
Oxytocin - a peptide serving manifold roles during the reproductive cycle in mares
}

\author{
J. Handler \\ Klinik für Geburtshilfe, Gynäkologie und Andrologie, Veterinärmedizinische Universität Wien
}

\begin{abstract}
Summary
Oxytocin, a peptide hormone released by the posterior pituitary, has important tasks in the reproductive biology in the mare. Functions of OT are based on its effects on smooth muscle cells of the myometrium and the myoepithelia in the mammary gland. Uterine clearance as a part of uterine defense mechanisms, delivery of the foal at parturition and milk let down in lactating mares are familiar examples. During luteolysis, oxytocin stimulates the endometrial release of prostaglandin $\mathrm{F}_{2 a}$. The consequences of the provoked secretion of oxytocin, by manipulations of the genital tract on the endocrine regulation of luteal function and on the course of the oestrous cycle are still under discussion. Furthermore, the modulating role of oxytocin on neuroendocrine events is hardly investigated in the horse up to now.
\end{abstract}

Keywords: $\quad$ mare, oxytocin, estrous cycle, pregnancy, therapy

\begin{abstract}
Oxytozin - ein Peptidhormon mit vielfältigen Aufgaben während des Reproduktionszyklus der Stute
Oxytozin, ein vom Hypophysenhinterlappen freigesetztes Peptidhormon, übernimmt wichtige Aufgaben im Rahmen des Fortpflanzungsgeschehens der Stute. Seine wesentlichen Funktionen beruhen auf seinen Wirkungen auf die glatten Muskelzellen des Myometriums und der Myoepithelien in der Milchdrüse. Beispiele dafür sind die Unterstützung der Selbstreinigung der Gebärmutter, die Austreibungswehen während der Geburt sowie die Milchejektion der laktierenden Stute. Während der Luteolyse stimuliert Oxytozin die Freisetzung von Prostaglandin $F_{2 a}$ durch das Endometrium. Die Konsequenzen der provozierten Freisetzung von Oxytozin durch Manipulationen am Genitaltrakt sind noch nicht ausreichend geklärt. Vor allem über die modulierende Wirkung von Oxytozin auf neuroendokrine Vorgänge ist bei der Stute bislang nur wenig bekannt.
\end{abstract}

Schlüsselwörter: Stute, Oxyłozin, Sexualzyklus, Trächtigkeit, Therapie

\section{Introduction}

Oxytocin (OT) is a very abundant neuropeptid. The functions of OT range from the modulation of neuroendocrine reflexes to the establishment of complex social and bonding behaviors related to reproduction and care of the offspring. Its action on smooth muscles, e.g. on the myometrium and on the myoepithelia of mammary alveoli, are well known in the mare, but its role concerning luteolysis and its effects on luteal function remain still unclear. The equine OT, as in other mammals, is a nonapeptid: Cys-Tyr-Ile-Gln-Asn-Cys-Pro-Leu-Gly $\left(\mathrm{NH}_{2}\right)(\mathrm{Gimpl}$ and Fahrenholz 2001). Nerve cells of the supraoptic, paraventricular and arcuate nuclei of the hypothalamus produce a large precursor molecule, which is split into neurophysin and OT during its transport via neurons to the posterior pituitary (Gainer et al. 1985). In the nerve terminals, OT is then stored in neurosecretory granula, from where it is released into the venous blood system. Half-time period of OT is short in mares: 6.8 minutes (Paccamonti et al. 1999).

OT acts on target cells by binding to OT-receptors, which are located in various tissues also out of the genital tract (Gimpl and Fahrenholz 2001). Only few data are available on the distribution of OT-receptors in the mare. Watson et al. (1999) attributed the presence of OT in small lutein cells and in ovarian blood vessels, without any detectable amounts of neurophysin, to the binding of OT to OT-receptors. Concentrations of OTreceptors in the equine myometrium are threefold higher than in the endometrium (Stull and Evans 1986). Sharp et al. (1997) investigated density and affinity of OT-receptors during the oestrous cycle and early pregnancy. Receptor density was lowest in mares at oestrus and highest in nonpregnant mares on day 14 and receptor affinity was decreased in pregnant mares.

\section{Oestrous cycle}

The importance of OT for sexual function in the mare throughout the cycle is demonstrated by the fact, that it is secreted in pulsatile rhythms during the entire oestrous cycle. Merely, the length of the rhythms and the amplitudes of the peaks are varying dependent from the respective stage of the cycle (Tetzke et al. 1987).

In the horse, mating is a complex interaction of sensory, psychic and mechanical stimuli involving teasing, mounting, intromission and ejaculation by the stallion. It is known that mating is able to stimulate OT secretion in oestrous mares (Alexander et al. 1995, Nikolakopoulos et al. 2000), whereas teasing was shown to be effective only in individual mares (Nikolakopoulos et al. 2000, Madill et al. 1998). OT increases uterine motility at oestrus to likely enhance the transport of sperm cells to the oviduct on the one hand and to support uterine defense by stimulating the clearance of the uterine lumen on the other hand (LeBlanc et al. 1994, Pycock 1993). Compared to the situation during dioestrus, the ability of OT to stimulate prostaglandin $\mathrm{F}_{2 \alpha}\left(\mathrm{PGF}_{2 \alpha}\right)$ 
release is markedly reduced during oestrus (Goff et al. 1987). From these findings was concluded, that the effect of OT on the myometrium is a direct one without any contribution of $\mathrm{PGF}_{2 \alpha}$ Interestingly, dioestrous mares release OT as well, when they are exposed to stallions (Nikolakopoulos et al. 2000). While earlier studies stated that OT has no function concerning the luteolytic pathway (Arthur 1975, Neely et al. 1979), Betteridge et al. (1985) could provoke a rise of the PGF ${ }_{2 \alpha}$ metabolite 13,14dihydro-15-keto PGF ${ }_{2 \alpha}$ (PGFM) by the application of OT to dioestrous mares. This finding was supported by Goff et al. (1987), who obtained maximum PGFM response to OT at the time of expected luteolysis. Tetzke et al. (1987), Sharp et al. (1997) and Starbuck et al. (1998) found that the OT-receptors have increased binding affinity at that time. Endometrial biopsies, cultured in vitro, responded to the supplementation of OT by secretion of prostaglandin (King and Evans 1987). The continuous application of OT beginning at day 8 after ovulation prolonged luteal function in mares, what may be caused by inhibition of the upregulation of OT-receptors, and therefore abolished luteolysis (Stout et al. 1999). Daily application of OT to mares at days $4,5,6,7$ and 8 of the oestrous cycle had no effect on PGFM concentrations and duration of dioestrus (Neely et al. 1979), supporting the hypothesis of downregulated OTreceptors up to day 10 of the cycle. In contrast, Vanderwall et al. (1998) could not find synchronous OT and PGFM patterns in blood samples, which were drawn from the cavernous sinus during luteolysis, although they support the positive feedback role of OT on $\mathrm{PGF}_{2 \alpha}$ as well.

\section{Pregnancy, birth and lactation}

In early pregnant mares the conceptus has to prevent the endometrium from initiating luteolysis. Therefore, the equine conceptus is supposed to release a still unknown embryonic signal, similar to the protein hormone interferon-t in ruminants (Lamming et al. 1995), which is likely to suppress the upregulation of endometrial OT receptors. It has been clearly shown by in vivo (Goff et al. 1987, Sharp et al. 1997, Starbuck et al. 1998) as well as in vitro studies (Franklin et al. 1989), that the stimulatory effect of OT on the secretion of prostaglandin is markedly reduced or abolished during early pregnancy. Administration of OT or OT-inducing manipulations provoked no or a very small rise in plasma PGFM-concentrations, when compared to cycling mares. This inhibition of PGF release was not associated with suppression of oxytocin release or decrease in oxytocin receptor density (Sharp et al. 1997).

Nevertheless, concentrations of OT remain at basal levels during the entire pregnancy until birth (Haluska and Currie 1988) and OT is released immediately at the beginning of the second stage of labor, closely related to the rupture of placental membranes. Allen et al. (1973), Pashen (1984), Haluska and Currie (1988), Haluska (1989) and Vivrette et al. (2000) observed peak concentrations of OT during the delivery of the foal in the mare. After parturition, OT-secretion appeared to be episodic during a period from delivery of the foal up to one hour after the expulsion of the placenta (Vivrette et al. 2000). OT-concentrations decrease within one hour (Haluska
1989) up to four hours (Haluska and Currie 1988) to basal levels.

OT is also involved in lactation in mares. Milk ejection can be provoked by psychogenic factors and suckling (Sharma 1974) and inhibited by stress and anxiety. Ellendorf and Schams (1988) obtained rises of intramammary pressure associated with peak OT levels as well as after application of exogenous OT. Even though milk let down was also observed without any measurable OT concentrations in lactating mares (Vivrette et al. 2000).

\section{Exogenous mechanic stimulation}

A series of exogenous, mechanic stimuli have been shown to promote OT secretion in mares. Manual manipulation of the clitoris, vagina and cervix, intrauterine infusion of PBS (Nikolakopoulos et al., 2000), and uterine biopsies (Sharp et al. 1997) caused significant OT releases. Paccamonti et al. (1999) obtained eightfold increases of OT concentrations in plasma from the cavernous sinus due to cervical manipulation. Endogenous opiods are likely to suppress the OT response to vaginocervical stimulation in periparturient mares (Aurich et al. 1996). The effects of OT secretion on subsequent PGF release depends from the respective stage of oestrous cycle. Maximum PGFM response to uterine biopsies could be achieved at days 12 and 14 in cycling mares (Sharp et al. 1997).

Reports concerning the effects of cervical manipulation on secretion of $\mathrm{OT}$ and subsequent $\mathrm{PGF}_{2 \alpha}$ release and diestrous length are conflicting. Insertion of aluminum rods into the cervix did not alter the estrous cycle (Arthur 1975), and manual dilatation of the cervical canal was shown by Hurtgen (1975), Hurtgen and Whitmore (1978), and Hurtgen and Ganjam (1979) to shorten dioestrus. Berglund et al. (1982) measured higher $\mathrm{PGF}_{2 \alpha}$ concentrations in uterine flushing solutions obtained through the cervix, when compared to the hysterectomy technique. In contrast, Wilde et al. (1989) could not find any effect of cervical stimulation, performed by placing an external sheath from an embryo transfer catheter for 60 seconds in the cervix and the caudal part of the corpus uteri. Therefore, we developed a standardized dilatation method for the cervix, which has no or only little effect on the other genital organs (Handler et al. 2000). Dilatation of the cervical lumen up to a diameter of $40 \mathrm{~mm}$ had no effect on plasma PGFM, but PGFM concentrations increased slightly during distension of the vagina through a speculum. Anyway, dilatation was accompanied by a distinct secretion of OT, and length of estrous cycle as well as of diestrus were significantly shortened by two days in dilatation group when compared to control mares, but the mechanisms of these effects remain still unclear.

\section{Therapeutic considerations}

Therapeutic use of OT is based on its impact on the myometrium and the myoepithelia of the mammary gland, respectively. Therefore, indications for its use are to support of uterine 
clearance, to induce foaling, to release retained placenta and to facilitate milk let down in nursing mares.

Evacuation studies performed with radiocolloids (LeBlanc et al. 1994, Cadario et al. 1999), the measurement of intrauterine tone or myometrial electric activity (Goddard and Allen 1985, Sharpe et al. 1988, Jones et al. 1991, Gutjahr, et al. 2000) and clinical trials (Pycock 1993, Rasch et al. 1996) showed the ability of oxytocin to improve myometrial activity and uterine clearance. Gastal et al. (1998) found the action of OT by scoring realtime ultrasound images to be more likely based on increased uterine tone than on myometrial contractions. However, the supportive effect of OT on uterine clearance is dose dependent: higher doses (25 IU) have been proven to be much more effective than lower doses of OT (10 IU) by Gutjahr et al. (2000). Furthermore, the intravenous route of application resulted in a higher myometrial response than intramuscular or intrauterine administration (Sharpe et al. 1988).

Oxytocin (40 to $60 \mathrm{IU}$ ) given intramuscularly induces parturition within 30 minutes. Macpherson et al. (1997) compared the effects of three different OT treatment regimens on delivery and outcome of newborn foals, when 75 IU OT were administered as a single dose or as 5 doses in 15 minutes intervals intramuscularly or as an intravenous infusion. The prevalence of intrapartum complications did not differ among treatment groups. Merely the interval from induction to the rupture of the chorioallantois and to the delivery of the foals was longer when OT was given dose by dose intramuscularly. Ripening of the cervix with prostaglandin $\mathrm{E}$ appears to favor shortened deliveries and to improve foal vigor (Rigby et al. 1998).

Another use of OT is to facilitate milk let down in lactating mares. Chavatte (1997) recommends 1 to 2 IU for successful stimulation of milk ejection to make sucking or milking easier, while Neely (1983) states doses between 10 and 40 IU OT.

\section{Conclusion}

OT contributes to many reproductive events in the mare and is therefore a useful and potent drug in equine medicine, unless the fact that not all its effects on oestrous cycle and genital functions are elucidated in detail now.

\section{Literature}

Alexander, Susan L.; Irvine, C. H. G.; Shand, N. and M. J. Evans (1995): Is luteinizing hormone secretion modulated by endogenous oxytocin in the mare? Studies on the role of oxytocin and factors affecting its secretion in estrous mares. Biol Reprod Mono 1, 361-371.

Allen, W. E.; Chard, T. and M. L. Forsling (1973): Peripheral plasma levels of oxytocin and vasopressin in the mare during parturition. J Endocrinol 57, 175-176.

Arthur, G. H. (1975): Influence of intrauterine saline infusion upon the oestrous cycle of the mare. J Reprod Fert Suppl 23, 231-234.

Aurich, J. E.; Besognet, B. and P. F. Daels, (1996): Evidence for opioidergic inhibition of oxytocin release in periparturient mares. Theriogenology 46, 387-396.

Berglund, L. A.; Sharp, D. C.; Vernon, M. W. and W. W. Thatcher (1982): Effect of pregnancy and collection technique on prostaglandin $\mathrm{F}$ in the uterine lumen of Pony mares. J Reprod Fert Suppl 32, 335-341.
Betteridge, K. J.; Renard, A. and A. K. Goff (1985): Uterine prostaglandin release relative to embryo collection, transfer procedures and maintenance of the corpus luteum. Equine Vet J Suppl 3, 25-33.

Cadario, Maria E.; Thatcher, W. W.; Klapstein, E.; Merrit, A. M.; Archbald, L. F.; Thatcher, Marie-Joelle and Michelle M. LeBlanc (1999): Dynamics of prostaglandin secretion, intrauterine fluid and uterine clearance in reproductively normal mares and mares with delayed uterine clearance. Theriogenology 42, 1181-1 192.

Chavatte, Pascale (1997): Lactation in the mare. Equine Vet Ed 9, 62 67.

Ellendorff, F. and D. Schams (1988): Characteristics of milk ejection, associated intramammary pressure changes and oxytocin release in mares. J Endocrinol 119, 219-227.

Franklin, K. J.; Gross, T. S.; Dubois, D. A. and D. C. Sharp (1989): In vitro prostaglandin secretion from luminal and myometrial sides of the endometrium from cyclic and pregnant mares. Procc Society for the Study of Reproduction Annual Meeting, Biol Reprod Suppl 40, Al 14 .

Gainer, H.; Russel, J. T. and Y. P. Loh (1985): The enzymology and intracellular organization of peptide precursor processing: The secretory vesicle hypothesis. Neuroendocrinology 40, 171-184.

Gastal, M. O.; Gastal, E. L.; Torres, C. A. A. and O. J. Ginther (1998): Effect of oxytocin, prostaglandin $F_{2 \alpha}$ and clenbuterol on uterine dynamics in mares. Theriogenology 50, 521-534.

Gimpl, G. and F. Fahrenholz (2001): The oxytocin receptor system: structure, function, and regulation. Physiol Reviews 81, 629-683.

Goddard, P. J. and W. E. Allen (1985): Genital tract pressures in mares II. Changes induced by oxytocin and prostaglandin $\mathrm{F}_{2 \alpha}$. Theriogenology 24, 35-44.

Goff, A. K.; Pontbriand, D. and J. Sirois, (1987): Oxytocin stimulation of plasma 15-keto-13,14-dihydro prostaglandin F-2 $\alpha$ during the oestrous cycle and early pregnancy in the mare. J Reprod Fert Suppl 35, 253-260.

Gutjahr, S.; Paccamonti, D. L.; Pycock, J. F.; Taverne, M. A. M.; Dieleman, S. J. and G. C. van der Weijden (2000): Effect of dose and day of treatment on uterine response to oxytocin in mares. Theriogenology 54, 447-456.

Haluska, G. J. (1989): Trächtigkeit und Geburt bei der Stute: Uterine Aktivität und Endokrinologie. Tierärztl Prax Suppl 4, 56-62.

Haluska, G. J. and W. B. Currie (1988): Variation in plasma concentrations of oestradiol-17B and their relationship to those of progesterone, 13,14-dihydro-15-keto-prostaglandin F-2 $\alpha$ and oxytocin across pregnancy and at parturition in pony mares. J Reprod Fert 84, 635-646.

Handler, J.; Königshofer, M.; Kindahl, H. and Christine Aurich (2000): Effects of vaginocervical manipulation on oestrous cycle length and prostaglandin release in mares. Reprod Dom Anim 35, 180-181.

Hurtgen, J. P. (1975): Alterations of the equine estrous cycle following uterine and/or cervical manipulations. Procc $21^{\text {st }}$ A Conv AAEP, 368377.

Hurtgen, J. P. and V. K. Ganjam, (1979): The effect of intrauterine and cervical manipulation on the equine oestrous cycle and hormone profiles. J Reprod Fert Suppl 27, 191-197.

Hurtgen, J. P. and H. L. Whitmore (1978): Effect of endometrial biopsy, uterine culture, and cervical dilatation on the equine estrous cycle. JAVMA 173, 97-100.

Jones, D. M.; Fielden, E. D. and D. H. Carr (1991): Some physiological and pharmacological factors affecting uterine motility as measured by electromyography in the mare. J Reprod Fert Suppl 44, 357368.

King, S. S. and J. W. Evans (1987): Effects of arachidonic acid and oxytocin on equine endometrial $\mathrm{PGF}_{2 \alpha}$ during normal cycles and pseudopregnancy. Equine Vet Sci 7, 303-308.

Lamming, G. E.; Wathes, D. C.; Flint, A. P. F.; Payne, J. H.; Stevenson, K. R. and J. L. Vallet (1995): Local action of trophoblast interferons in suppression of the development of oxytocin and oestradiol receptors in ovine endometrium. J Reprod Fert 105, 165-175.

LeBlanc, Michelle M.; Neuwirth, Lisa; Mauragis, Danielle; Klapstein, Elisabeth and T. Tran (1994): Oxytocin enhances clearance of ra- 
diocolloid from the uterine lumen of reproductively normal mares and mares susceptible to endometritis. Equine Vet J 26, 279-282.

Macpherson, Margo L.; Chaffin, K. M.; Carroll, G. L.; Jorgensen, J.; Arrott, C.; Varner, D. D. and T. L. Blanchard (1997): Three methods of oxytocin-induced parturition and their effects on foals. JAVMA 210, 799-803.

Madill, S.; Troedsson, M .H. T.; Alexander, Susan L.; Shand, N.; Santschi, E. M. and C. H. G. Irvine (1998): Simultaneous recording of pituitary oxytocin secretion and myometrial activity in oestrous mares exposed to various breeding stimuli. Procc 7th Int Symp Equine Reprod, Pretoria, 93-94.

Neely, D. P. (1983): Hormone therapy in mares. In: Neely, D. P., Liu, I. K. M. and R. B. Hillman (Eds.): Equine reproduction. Veterinary Learning Systems, Hoffmann-LaRoche, New Jersey, 23-37.

Neely, D. P.; Stabenfeldt, G. H. and C. L. Sauter (1979): The effect of exogenous oxytocin on luteal function in mares. J Reprod Fert 55, 303-308.

Nikolakopoulos, E.; Kindahl, H.; Gilbert, C. L.; Goode, J. and Elaine D. Watson (2000): Release of oxytocin and prostaglandin $\mathrm{F}_{2 \alpha}$ around teasing, natural service and associated events in the mare. Anim Reprod Sci 63, 89-99.

Paccamonti, D. L.; Pycock, J. F.; Taverne, M. A. M.; Bevers, M.; van der Weijden, G. C.; Gutjahr, S.; Schams, D. and D. Blouin (1999): PGFM response to exogenous oxytocin and determination of the half-life of oxytocin in nonpregnant mares. Equine Vet J 31, 285-288.

Pashen, R. L. (1984): Maternal and foetal endocrinology during late pregnancy and parturition in the mare. Equine Vet J 16, 233-238.

Pycock, J. (1993): Early mating, intrauterine treatment and oxytocin Equine Vet J 25, 192-193.

Rasch, Kathrin; Schoon, H. A.; Sieme, H. and E. Klug (1996): Histomorphological endometrial status and influence of oxytocin on the uterine drainage and pregnancy rate in mares. Equine Vet J 28, 455460.

Rigby, S.; Love, C.; Carpenter, K.; Varner, D. and T. Blanchard (1998): Use of prostaglandin E2 to ripen the cervix of the mare prior to induction of parturition. Theriogenology 50, 897-904.

Sharma, O. P. (1974): Release of oxytocin elicited by suckling stimulus in mares. J Reprod Fert 37, 421-423.

Sharp, D. C., Thatcher, Marie-Joelle, Salute, M. E. and A.-R. Fuchs (1997): Relationship between endometrial oxytocin receptors and oxytocin-induced prostaglandin $\mathrm{F}_{2 \alpha}$ release during oestrous cycle and early pregnancy in pony mares. J Reprod Fert 109, 137-144.

Sharpe, K. L.; Eiler, H. and F. M. Hopkins (1988): Absence or uterokinetic effects of prostaglandin $\mathrm{F}_{2 \alpha}$ on oxytocin-reactive uterus in the mare. Theriogenology 30, 887-892.

Starbuck, G. R.; Stout, T. A. E.; Lamming, G. E.; Allen, W. R and A. P. F. Flint (1998): Endometrial oxytocin receptor and uterine prostaglan- din secretion in mares during the oestrous cycle and early pregnancy. J Reprod Fert 113, 173-179.

Stout, T. A. E.; Lamming, G. E. and W. R. Allen (1999): Oxytocin administration prolongs luteal function in cycling mares. J Reprod Fert $116,315-320$.

Stull, C. L. and J. W. Evans (1986): Oxytocin binding in the uterus of the cycling mare. Equine Vet Sci 6, 114-119.

Tetzke, T. A.; Ismail, S.; Mikuckis, G. and J. W. Evans (1987): Patterns of oxytocin secretion during the oestrous cycle of the mare. J Reprod Fert Suppl 35, 245-252.

Vanderwall, D. K.; Silvia, W. J. and B. P. Fitzgerald (1998): Concentrations of oxytocin in the intercavernous sinus of mares during luteolysis: temporal relationship with concentrations of 13,14-dihydro-15keto-prostaglandin $\mathrm{F}_{2 \alpha}$. J Reprod Fert 1 12, 337-346.

Vivrette, S. L.; Kindahl, H.; Munro, C. J.; Roser, Janet F. and G. H. Stabenfeldt (2000): Oxytocin release and its relationship to dihydro15-keto PGF $_{2 \alpha}$ and arginine vasopressin release during parturition and suckling in postpartum mares. J Reprod Fert 1 19, 347-357.

Watson, Elaine D., Buckingham, Joanne and T. S. Biörksten (1999): Immuno-localisation of oxytocin in the equine ovary. Equine Vet J 31, 174-175.

Wilde, M. H.; Dinger, J. E.; Hoagland, T. A.; Graves-Hoagland, R. L. and C. O. Woody (1989): The effects of cervical dilatation on plasma PGFM, progesterone and the duration of luteal function in diestrous mares. Theriogenology 32, 675-681.

\section{Dr. Johannes Handler}

Klinik für Geburtshilfe, Gynäkologie und Andrologie

Veterinärmedizinische Universität Wien

Veterinärplatz 1

A-1210 Wien

Tel.: 0043-1-25077-5410

Fax: 0043-7-25077-5490

e-mail: Johannes.Handler@vu-wien.ac.at

Present address

Animal Biotechnology Embryo Laboratory

Department of Biomedical Sciences

Ontario Veterinary College/University of Guelph

Guelph ON N1G 2W1

Tel: 001-519-8244120 ext. \#8261

e-mail: Johannes.Handler@vu-wien.ac.at 